\title{
Aluminum Doped Titania as a Support of Copper Catalysts for SCR of Nitrogen Oxides
}

\author{
Wojciech Guziewicz ${ }^{1}$, Anna Białas ${ }^{1, *(D)}$, Bogna D. Napruszewska ${ }^{2}$, Małgorzata Zimowska ${ }^{2}$ and Jacek Gurgul $^{2}$ \\ 1 Faculty of Energy and Fuels, AGH University of Science and Technology, Mickiewicza 30, \\ 30059 Kraków, Poland; wguziewicz@student.agh.edu.pl \\ 2 Jerzy Haber Institute of Catalysis and Surface Chemistry, Polish Academy of Sciences, Niezapominajek 8, \\ 30239 Kraków, Poland; ncnaprus@cyf-kr.edu.pl (B.D.N.); malgorzata.zimowska@ikifp.edu.pl (M.Z.); \\ jacek.gurgul@ikifp.edu.pl (J.G.) \\ * Correspondence: anbialas@agh.edu.pl
}

check for updates

Citation: Guziewicz, W.; Białas, A.; Napruszewska, B.D.; Zimowska, M.; Gurgul, J. Aluminum Doped Titania as a Support of Copper Catalysts for SCR of Nitrogen Oxides. Materials 2021, 14, 6021. https://doi.org/ $10.3390 / \mathrm{ma} 14206021$

Academic Editor: Zahra Gholami

Received: 10 September 2021

Accepted: 7 October 2021

Published: 13 October 2021

Publisher's Note: MDPI stays neutral with regard to jurisdictional claims in published maps and institutional affiliations.

Copyright: (c) 2021 by the authors. Licensee MDPI, Basel, Switzerland. This article is an open access article distributed under the terms and conditions of the Creative Commons Attribution (CC BY) license (https:/ / creativecommons.org/licenses/by/ $4.0 /)$.

\begin{abstract}
Aluminum doped titania samples were synthesized as supports of copper oxide catalysts for NO reduction with ammonia. Samples were prepared by the sol-gel method with various ratios of aluminum to titanium. Their thermal stability was examined by TG/DSC methods which revealed that precursors were decomposed at $450^{\circ} \mathrm{C}$. The XRD measurements showed that aluminum caused the diminishing of titania crystallites and was built into the anatase structure or formed an amorphous phase. The admixture of aluminum in titania resulted in a significant increase in specific surface area of mesoporous supports as determined by low temperature sorption of nitrogen. Results of the catalytic tests over copper/aluminum-titania samples obtained by impregnation pointed out that the addition of aluminum broadened the temperature window of high catalytic activity. The increase in Al concentration shifted the temperature of maximum activity to higher values, and at the same time lowered nitrous oxide formation as well. Better catalytic efficiency could result from high copper dispersion on the catalysts surface, as well as the synergistic interaction between $\mathrm{Ti}$ and $\mathrm{Cu}$ causing reduction in $\mathrm{CuO}$ species as confirmed by XPS measurements. It was shown that copper was present as $\mathrm{Cu}^{+}$species mainly, forming $\mathrm{Cu}-\mathrm{O}-\mathrm{Ti}$ bonds on the catalysts surface.
\end{abstract}

Keywords: sol-gel method; titanium oxide; aluminum; anatase; SCR; nitrogen oxides

\section{Introduction}

Among the catalysts used in selective catalytic reduction (SCR) of nitrogen oxides $\left(\mathrm{NO}_{\mathrm{x}}\right)$ with ammonia, copper oxide is regarded as a highly efficient active phase. However, it must occur as isolated or dimeric species in the catalyst because crystalline $\mathrm{CuO}$ exhibits the narrow temperature window of its high catalytic activity [1,2]. Variable valence of copper, good dispersion, and strong acidic properties of a catalyst are crucial in SCR and were observed in coprecipitated $\mathrm{Cu}$-Ti systems [1]. In such systems, tuning Lewis-Brønsted acidity, responsible for the low or high temperature range of the reaction, respectively, ensures a broad temperature window. Well-chosen support can accelerate the $\mathrm{Cu}^{+} / \mathrm{Cu}^{2+}$ redox cycle and decrease the amount of oxidized $\mathrm{NH}_{3}$, as well as can improve the adsorption ability. Thus, the main challenge in preparing copper oxide catalysts is to widen the temperature window of their high activity [1]. It can be attained by elaborating the materials which enable good dispersion of copper species on the support and which are cheaper than zeolites. Among catalyst supports for the SCR process titania and alumina are widely used [3]. Alumina increases acidic properties making a catalyst less prone to $\mathrm{SO}_{2}$ adsorption, thus more resistant to $\mathrm{SO}_{2}$ poisoning. In case of titania, a similar behavior is also reported [1]. It is worth noting that alumina supported copper catalysts are active at higher temperatures and less nitrous oxide is formed than over titania ones [4]. This is a huge advantage because $\mathrm{N}_{2} \mathrm{O}$ is a greenhouse gas which damages the ozone layer [4]. The $\mathrm{N}_{2} \mathrm{O}$ formation is determined by the reaction temperature and the content of active 
phase. In case of copper catalysts, the concentration of $\mathrm{Cu}$ reduced form is responsible for this by-product [4]. The presence of $\mathrm{Al}_{2} \mathrm{O}_{3}$ develops the surface of catalyst and improves its hydrothermal resistance and inertness [1]. On the other hand, the active sites are more accessible on $\mathrm{TiO}_{2}$ than on $\mathrm{Al}_{2} \mathrm{O}_{3}$ [4]. Good textural and chemical properties of supports are attained when sol-gel method is used for their synthesis [5].

The aim of the presented paper was to elaborate the synthesis of aluminum doped titania by the sol-gel method to obtain the support ensuring good copper dispersion on the catalysts for SCR of NO. The physicochemical characterization of catalysts was carried out in detail to explain the catalyst activity in relation to the aluminum concentration in the support.

\section{Materials and Methods}

Glacial acetic acid (J.T. Baker, Deventer, Holland) was added to titanium isopropoxide (Acros Organics, Geel, Belgium) in the molar ratio of 10:1 and stirred for $30 \mathrm{~min}$. Then, the solution of a proper amount of aluminum nitrate (V) nonahydrate (Eurochem BGD, Tarnów, Poland) with distilled water (acid/water molar ratio equal 1:10) was added dropwise into the mixture for $40 \mathrm{~min}$. The samples with $\mathrm{Al}$ to Ti ratio equal to 1:9, 2:8, 3:7 or 4:6, as well as the sample without aluminum were prepared in this way. Initially, some white precipitate was formed which slowly dissolved forming clear solution. Then, the solution was maintained at $80^{\circ} \mathrm{C}$ for 100 min under stirring, slowly transforming into a gel. The gel was dried at $80{ }^{\circ} \mathrm{C}$ for 4 days. Obtained samples were ground and calcined at $450{ }^{\circ} \mathrm{C}$ for $3 \mathrm{~h}$. This temperature was determined on the base of thermogravimetric analyses (Figure S1, Supporting Information). The supports were marked as $\mathrm{Ti}, \mathrm{Ti}_{0.9} \mathrm{Al}_{0.1}, \mathrm{Ti}_{0.8} \mathrm{Al}_{0.2}, \mathrm{Ti}_{0.7} \mathrm{Al}_{0.3}$, and $\mathrm{Ti}_{0.6} \mathrm{Al}_{0.4}$.

The copper active phase was deposited with the incipient wetness impregnation method. Strictly defined amount of copper (II) nitrate (V) trihydrate (Acros Organics, Geel, Belgium) was dissolved in distilled water and deposited on obtained supports, resulting in $1 \mathrm{wt}$ \% of copper. The precursors were dried at $80{ }^{\circ} \mathrm{C}$ overnight and calcined at $450{ }^{\circ} \mathrm{C}$ for $3 \mathrm{~h}$. The catalysts were denoted as $\mathrm{Cu} / \mathrm{Ti}, \mathrm{Cu} / \mathrm{Ti}_{0.9} \mathrm{Al}_{0.1}, \mathrm{Cu} / \mathrm{Ti}_{0.8} \mathrm{Al}_{0.2}, \mathrm{Cu} / \mathrm{Ti}_{0.7} \mathrm{Al}_{0.3}$, and $\mathrm{Cu} / \mathrm{Ti}_{0.6} \mathrm{Al}_{0.4}$.

Thermogravimetric and differential scanning calorimetric analyses were conducted to determine the decomposition temperatures of support precursors. These analyses were carried out with a STA 409 PC Luxx by Netzsch-Gerätebau GmbH (Selb, Germany). The $20 \mathrm{mg}$ samples were subjected to the thermal treatment in the temperature range of $30{ }^{\circ} \mathrm{C}$ to $1000{ }^{\circ} \mathrm{C}$ with a temperature increase rate of $10^{\circ} \mathrm{C} \mathrm{min}-1$ under air flow of $30 \mathrm{~cm}^{3}$ $\min ^{-1}$. To measure the real content of metals, the XRF method was used. By means of an EDX $3600 \mathrm{H}$ spectrometer by Skyray Instrument (Dallas, Texas, USA) with a tungsten lamp calibration curves for $\mathrm{Al}_{2} \mathrm{O}_{3}, \mathrm{TiO}_{2}$, and $\mathrm{CuO}$ were prepared. The experimental error for these compounds was 2.7, 7.0, and $0.2 \%$, respectively. For light elements the lamp voltage was $9 \mathrm{kV}$, current $150 \mathrm{~mA}$, and the time of a measurement was equal to $200 \mathrm{~s}$, for elements heavier than Ca these parameters were $40 \mathrm{kV}, 450 \mathrm{~mA}$, and $100 \mathrm{~s}$, respectively. The crystallographic structure was examined by $\mathrm{X}$-ray diffraction with a PANalytical Empyrean diffractometer (Malvern, UK) with $\mathrm{CuK} \alpha$ radiation $(\lambda=1.54056 \AA)$. XRD patterns were recorded in the $2 \theta$ angle range of $3^{\circ}$ to $90^{\circ}$ with a step of $0.013^{\circ}$. The morphology of the solids was carried out by means of JEOL JSM-7500F field emission scanning electron microscope equipped with an retractable backscattered-electron detector (RBEI) and energy dispersive spectra (EDS) detection system of characteristic X-ray radiation INCA PentaFetx3 EDS system (Jeol Ltd., Tokyo, Japan). The low temperature sorption of nitrogen performed using a Nova 2200e sorptomat by Quantachrome Instruments (Boynton Beach, FL, USA) allowed to record isotherms and to determine the specific surface area of samples, as well as the pore size distribution and pore volume. Samples of $0.1 \mathrm{~g}$ were outgassed at $200{ }^{\circ} \mathrm{C}$ for $12 \mathrm{~h}$. The surface area was determined by the BET method, the volume pore distribution by the BJH method and the pore volume by the single point method. 
The X-ray photoelectron spectroscopy (XPS) experiments were carried out in a multichamber system equipped with a hemispherical analyzer (SES R4000, Gammadata Scienta, Uppsala, Sweden). The unmonochromatized Al $\mathrm{K}_{\alpha}(1486.6 \mathrm{eV}) \mathrm{X}$-ray source was used to generate core excitations. The anode was operating at $12 \mathrm{kV}$ and $15 \mathrm{~mA}$ current emission. The energy resolution of the system determined for $\mathrm{Ag} 3 \mathrm{~d}_{5 / 2}$ excitation line was $0.9 \mathrm{eV}$ (pass energy $100 \mathrm{eV}$ ). The spectrometer was calibrated according to ISO 15472:2001. The base pressure in the analysis chamber was about $1 \times 10^{-10} \mathrm{mbar}$ and about $5 \times 10^{-9}$ mbar during the experiment. The powder samples were examined after pressing into indium foil and mounting on a special holder. The area of sample analysis was about $4 \mathrm{~mm}^{2}(5 \mathrm{~mm} \times 0.8 \mathrm{~mm})$. High-resolution spectra were collected at pass energy of $100 \mathrm{eV}$ (with $25 \mathrm{meV}$ step), whereas survey scans at pass energy of $200 \mathrm{eV}$ (with $0.25 \mathrm{eV}$ step). The experimental curves were fitted in CasaXPS 2.3.23 software (Casa Software Ltd., Teignmouth, UK) with a combination of Gaussian and Lorentzian lines of variable proportions (70:30) after subtraction of the Shirley-type background. The relative intensity ratio of $2 \mathrm{p}_{3 / 2}$ and $2 \mathrm{p}_{1 / 2}$ lines in doublets was fixed to 2:1. All binding energy values were charge-corrected to the carbon C 1s excitation which set at $285.0 \mathrm{eV}$.

Selective catalytic reduction in nitrogen oxide with ammonia was performed over the obtained catalysts. $\mathrm{N}_{2} \mathrm{O}$ concentration was measured as well. An AO2020 IR detector by ABB Group (Frankfurt am Main, Germany) was used as an analyzer. Then, $0.2 \mathrm{~g}$ of the catalyst fraction between 0.25 and $1 \mathrm{~mm}$, was placed in a quartz reactor and outgassed at $450{ }^{\circ} \mathrm{C}$ for $1 \mathrm{~h}$ in a helium flow. Then, it was cooled down to $150{ }^{\circ} \mathrm{C}$ and the tests were conducted. The concentration of $\mathrm{NO}$ and $\mathrm{NH}_{3}$ was $800 \mathrm{ppm}$, the amount of $\mathrm{O}_{2}$ was 3.5\%, and helium was added to achieve the total flow of $100 \mathrm{~cm}^{3} \mathrm{~min}^{-1}$. The catalytic activity was measured within the temperature range of $150{ }^{\circ} \mathrm{C}$ to $450{ }^{\circ} \mathrm{C}$, with a step of $50{ }^{\circ} \mathrm{C}$ attained in $5 \mathrm{~min}$ and maintained for $30 \mathrm{~min}$. NO conversion $\left(\mathrm{X}_{\mathrm{NO}}\right)$ was calculated from the following equation:

$$
\mathrm{X}_{\mathrm{NO}}=\frac{\mathrm{n}_{\mathrm{NO}, 0}-\mathrm{n}_{\mathrm{NO}}}{\mathrm{n}_{\mathrm{NO}, 0}} \cdot 100 \%
$$

where: $\mathrm{n}_{\mathrm{NO}, 0}$ and $\mathrm{n}_{\mathrm{NO}}$ are the inlet and outlet streams of $\mathrm{NO}$, respectively.

\section{Results and Discussion}

\subsection{Composition, Crystallographic Structure, and Morphology}

The copper content and aluminum to titanium ratio are presented in Table 1 . Some differences between intended and measured values are observed, they could result from experimental errors during syntheses or XRF measurements.

Table 1. Composition, average crystallite size, and textural properties of Al-titania supported copper catalysts.

\begin{tabular}{|c|c|c|c|c|}
\hline \multicolumn{2}{|c|}{ Sample } & \multirow{2}{*}{$\begin{array}{c}\text { Average Crystallite Size } \\
{[\mathrm{nm}]}\end{array}$} & \multirow{2}{*}{$\begin{array}{c}\text { Surface Area * SSA } \\
{\left[\mathrm{m}^{2} \mathrm{~g}^{-1}\right]}\end{array}$} & \multirow{2}{*}{$\begin{array}{l}\text { Pore Volume * } \\
\qquad\left[\mathrm{cm}^{3} \mathrm{~g}^{-1}\right]\end{array}$} \\
\hline Nominal Formula & Measured Formula & & & \\
\hline $\mathrm{Cu} / \mathrm{Ti}$ & $1.1 \mathrm{Cu} / \mathrm{Ti}$ & 14.6 & 75 (97) & $0.203(0.225)$ \\
\hline $\mathrm{Cu} / \mathrm{Ti}_{0.9} \mathrm{Al}_{0.1}$ & $1.3 \mathrm{Cu} / \mathrm{Ti}_{0.90} \mathrm{Al}_{0.10}$ & 9.7 & $110(129)$ & $0.204(0.277)$ \\
\hline $\mathrm{Cu} / \mathrm{Ti}_{0.8} \mathrm{Al}_{0.2}$ & $1.3 \mathrm{Cu} / \mathrm{Ti}_{0.85} \mathrm{Al}_{0.15}$ & 8.8 & $131(178)$ & $0.233(0.256)$ \\
\hline $\mathrm{Cu} / \mathrm{Ti}_{0.7} \mathrm{Al}_{0.3}$ & $1.5 \mathrm{Cu} / \mathrm{Ti}_{0.74} \mathrm{Al}_{0.26}$ & 7.9 & $148(190)$ & $0.247(0.274)$ \\
\hline $\mathrm{Cu} / \mathrm{Ti}_{0.6} \mathrm{Al}_{0.4}$ & $1.6 \mathrm{Cu} / \mathrm{Ti}_{0.63} \mathrm{Al}_{0.37}$ & 7.5 & 145 (190) & $0.246(0.269)$ \\
\hline
\end{tabular}

* the values obtained for supports are shown in brackets.

Powder XRD patterns of the $\mathrm{Cu} / \mathrm{Ti}_{\mathrm{X}} \mathrm{Al}_{1-\mathrm{x}}$ samples are shown in Figure 1 . The diffraction lines observed for the $\mathrm{Cu} / \mathrm{Ti}$ sample at $2 \theta=25.3^{\circ}, 37.0^{\circ}, 37.7^{\circ}, 38.7^{\circ}, 48.0^{\circ}, 53.8^{\circ}$, $55.0^{\circ}, 62.6^{\circ}, 68.6^{\circ}, 70.2^{\circ}, 74.9^{\circ}, 82.5^{\circ}$, can be ascribed to the (101), (103), (004), (112), (200), (105), (211), (204), (116), (220), (215), and (224) planes of the anatase structure, respectively [01-071-1167]. The addition of aluminum to the titania precursor and the copper deposition did not cause the appearance of new phases. It suggests that aluminum could build into the anatase structure or occurs as amorphous phase. One can note, that the incorporation of $\mathrm{Al}$ 
into the titania structure should be visible by a little change of the (101) peak position due to difference in the ionic radii of $\mathrm{Al}^{3+}(0.53 \AA)$ and $\mathrm{Ti}^{4+}(0.60 \AA)$. Because the shift of (101) peak position is not seen, we believe that introduced aluminum occurs as amorphous alumina phase. There are no traces of any copper phases in the XRD patterns which suggests that copper, present in a small concentration, occurs as a well dispersed phase.

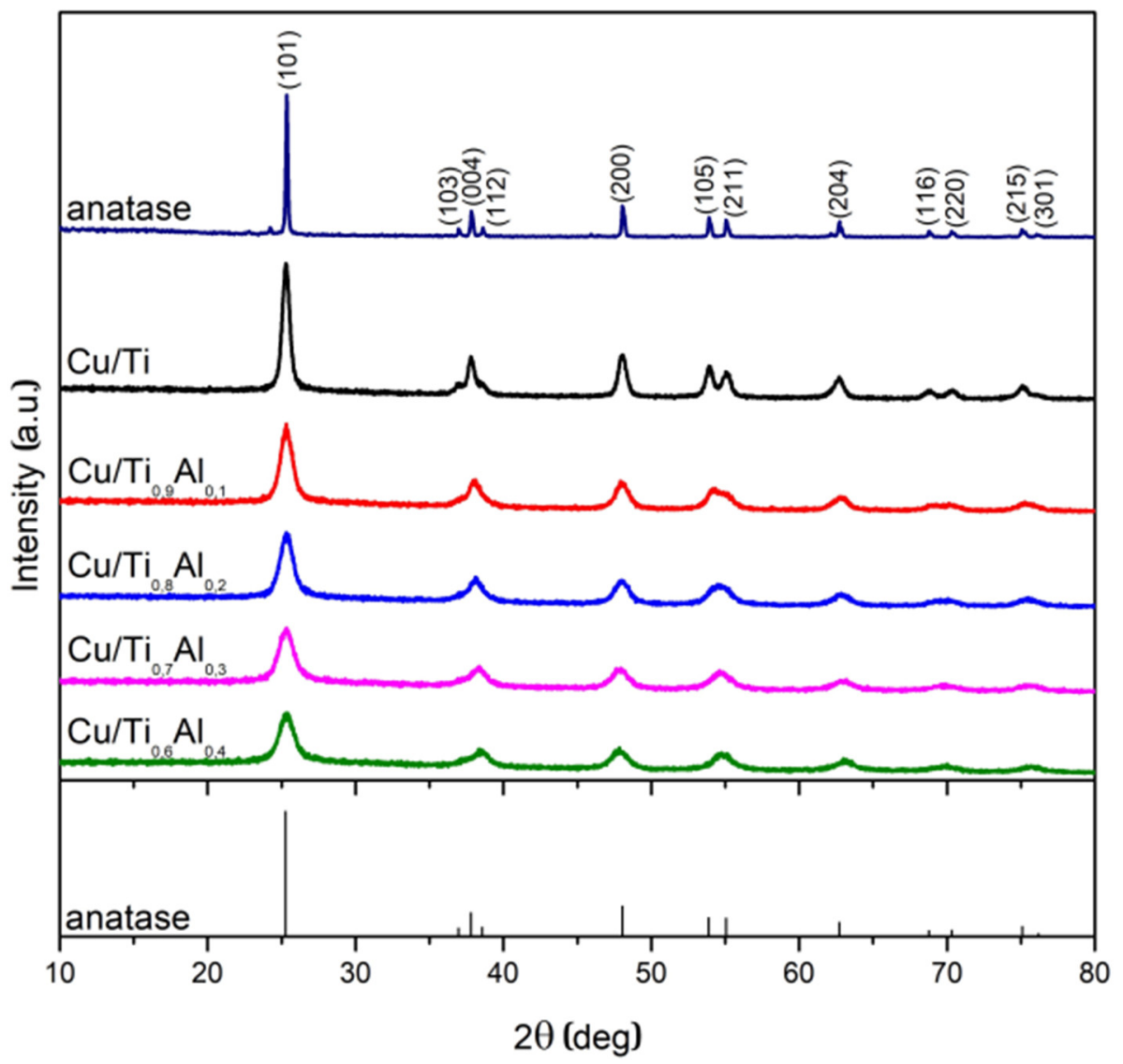

Figure 1. XRD patterns of $\mathrm{Cu} / \mathrm{Ti}_{\mathrm{X}} \mathrm{Al}_{1-\mathrm{x}}$ catalysts and the reference-commercial $\mathrm{TiO}_{2}$ anatase compared with data [01-071-1167].

With an increase in the aluminum content one can observe the decrease in maxima intensities, as well as widening of the peak FWHM, resulting in smaller crystallite sizes (D), which was confirmed by their estimation using the Scherrer equation:

$$
D=\frac{K \cdot \lambda}{\beta \cdot \cos \theta}
$$

where: $K$ is the shape factor (0.9), $\lambda$ is the wavelength of X-ray (1.54056 $\AA$ ), $\beta$ is FWMH of (101) reflex at $25.3^{\circ}, \theta$ is the Bragg angle.

Table 1 shows that the average crystallite size of the copper catalyst supported on titania was close to $15 \mathrm{~nm}$ and decreases significantly after aluminum addition.

Figures 2 and 3 show the SEM images with the morphology of the Al-titania supported copper catalysts. The titanium catalyst has a porous morphology and is characterized by the presence of tiny particles about $20-30 \mathrm{~nm}$ in size. The incorporation of $\mathrm{Al}$ into titania support results in formation of more dense materials. Comparison of SEM and XRD analyses shows that the addition of $\mathrm{Al}$ into titanium isopropoxide can affect the termination of the crystallites of anatase growth and, finally, sticks to $\mathrm{TiO}_{2}$ particles as an amorphous phase. EDX analysis (Figure 3) revealed that the amount of introduced copper varied in the range of 0.9 to $1.4 \mathrm{wt} . \%$ for all samples. 


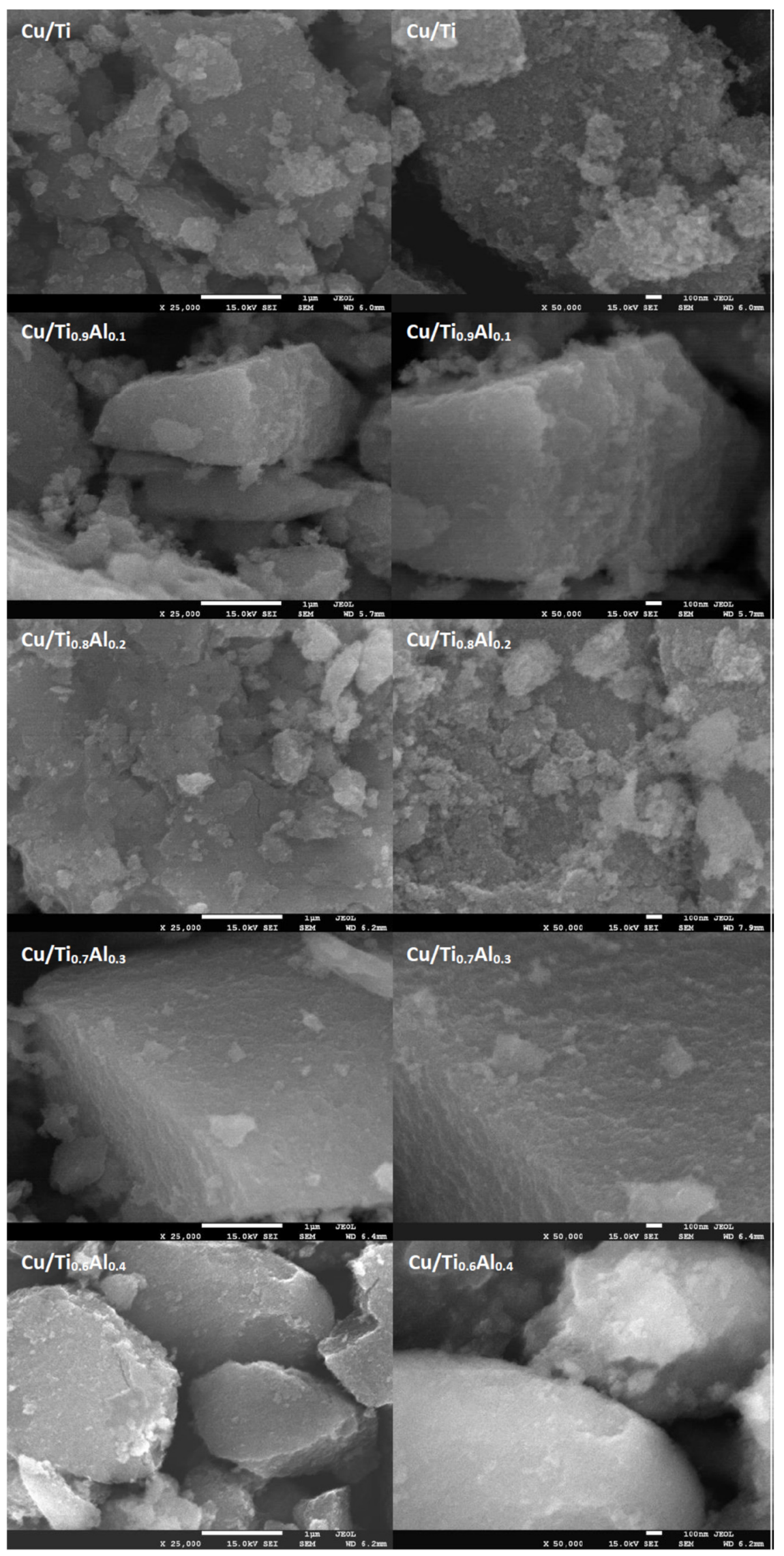

Figure 2. SEM images with the morphology of the Al-titania supported copper catalysts. 

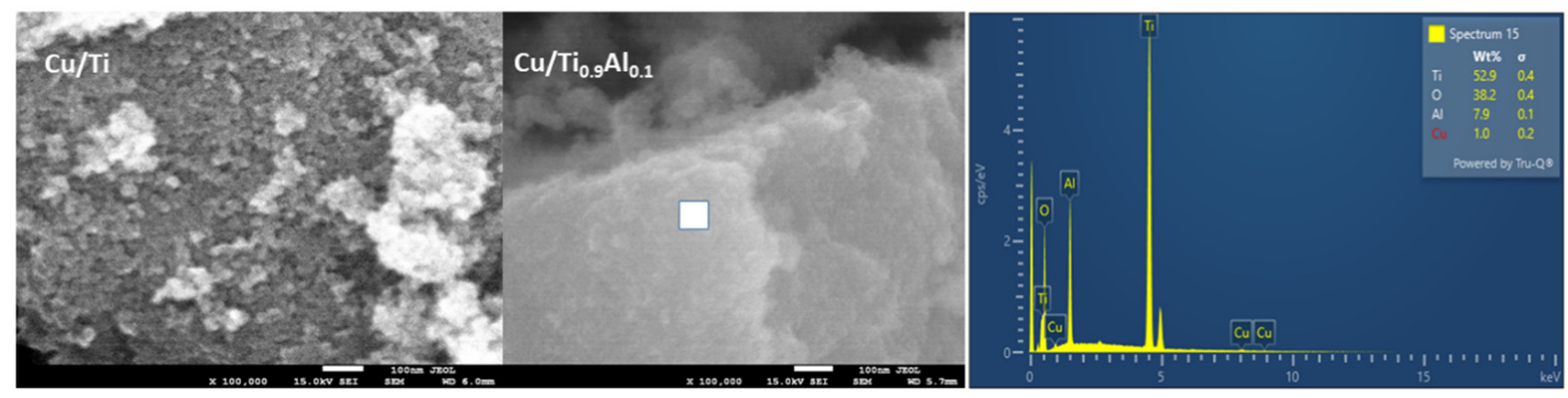

Figure 3. $\mathrm{SEM}$ images of $\mathrm{Cu} / \mathrm{Ti}$ and $\mathrm{Cu} / \mathrm{Ti}_{0.9} \mathrm{Al}_{0.1}$ catalysts obtained with maximum magnification. The EDX analysis performed in the selected area of $\mathrm{Cu} / \mathrm{Ti}_{0.9} \mathrm{Al}_{0.1}$ sample (marked by white square) is also shown.

\subsection{Textural Properties}

In Figure 4 the nitrogen sorption isotherms of catalysts are shown. The isotherms have characteristic hysteresis loops, which classified them as Type IV according to IUPAC. These characteristic shapes of isotherms are associated with the capillary condensation taking place in larger mesopores $(>4 \mathrm{~nm}$ ). Thus, the obtained materials can be classified as mesoporous. It can be noticed that with the increased amount of aluminum, the hysteresis loops move to lower values of relative pressure suggesting reduction in the pore size. This observation was confirmed by the pore size distribution presented in the inset of Figure 4 . For the titania supported catalyst the dominating pore size was $94 \AA$, and was attributed to the pore system predominantly form by inter-particle contacts. Aluminum doped catalysts show pore size distribution in the range of ca. $54 \AA$ and the lowering intensity of the maximum of the peaks with increasing amount of $\mathrm{Al}$ in the samples. These results confirm the covering of the $\mathrm{TiO}_{2}$ particles with alumina containing amorphous phase and shrinking of the inter-particle spaces. An increase in the amount of $\mathrm{Al}$ in the support increases the quantity of the amorphous component and results in the increase in the specific surface area of the supports. It is worth noting that in Type IV materials there is a correlation between the shape of the obtained hysteresis loop and the textural properties of the adsorbent. Here, we found the difference in hysteresis shapes between Ti-Al supported catalysts (Type H2) and titania one (close to Type H1), which leads to the conclusion that the pore structure in studied materials changed as well. As seen from Table 1, the titania support exhibited BET specific surface area of $97 \mathrm{~m}^{2} \mathrm{~g}^{-1}$. The substitution of titanium by low amount of aluminum caused significant increase in surface area. Further, an increase in aluminum content (up to $40 \%$ ) resulted in further increase in $\mathrm{SSA}_{\mathrm{BET}}$, as seen for the $\mathrm{Ti}_{0.7} \mathrm{Al}_{0.3}$ sample, and only slight changes in the case of the $\mathrm{Ti}_{0.6} \mathrm{Al}_{0.4}$ one. The total pore volume increased by about $20 \%$ for all supports containing aluminum. The deposition

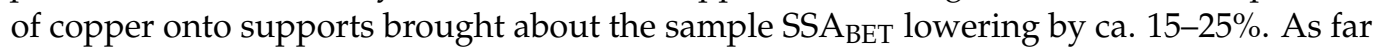
as the total pore volume is regarded the copper addition resulted in ca. $10 \%$ decrease in all samples with the exception of the $\mathrm{Cu} / \mathrm{Ti}_{0.9} \mathrm{Al}_{0.1}$ catalyst in which the pore volume is lowered by ca. $25 \%$. In the case of this sample, the copper phase is placed mainly on the outer surface of the supporting particles.

\subsection{Surface Composition-XPS}

The relative abundance of elements at catalysts surface obtained from the XPS survey scans in depth of max. $8.5 \mathrm{~nm}$ are presented in Table 2. It is computed by the assumption that samples are made of pure and uniform $\mathrm{TiO}_{2}$ with density equal to $4.26 \mathrm{~g} \mathrm{~cm}^{-3}$ [6]. The calculations present $95 \%$ of all photoelectrons escaping from the surface. The highresolution spectra of $\mathrm{Cu} 2 \mathrm{p}, \mathrm{Ti} 2 \mathrm{p}, \mathrm{O} 1 \mathrm{~s}, \mathrm{C} 1 \mathrm{~s}$, and $\mathrm{Al} 2 \mathrm{p}$ were used to investigate the chemical states of the active phase in the fresh and used catalysts. 


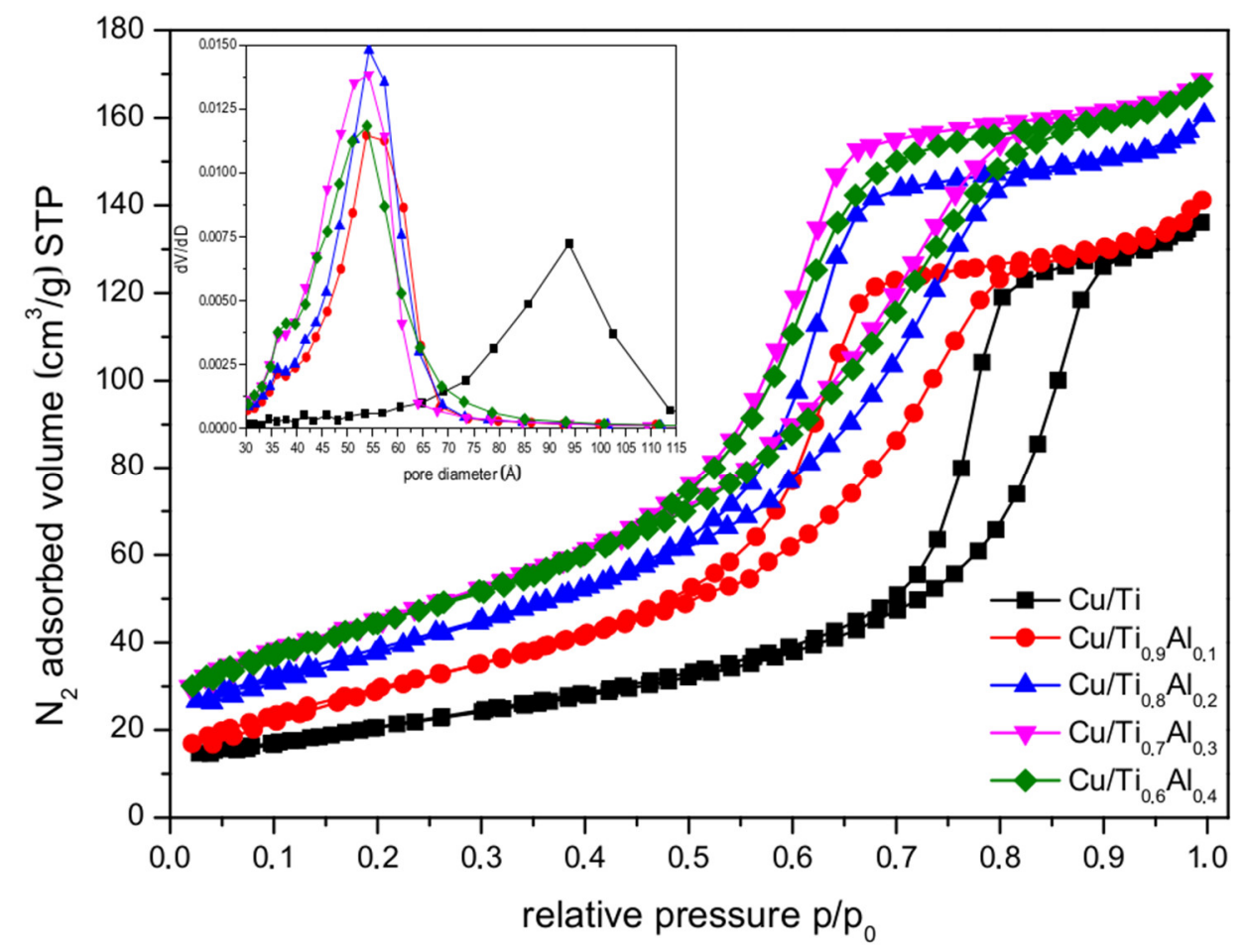

Figure 4. Nitrogen sorption isotherms and $\mathrm{BJH}$ pore distribution (inset) of $\mathrm{Cu} / \mathrm{Ti}_{\mathrm{x}} \mathrm{Al}_{1-\mathrm{x}}$ catalysts.

Table 2. Surface elemental composition of fresh and used catalysts (at.\%).

\begin{tabular}{|c|c|c|c|c|c|c|}
\hline Sample & $\mathrm{C}$ & $\mathbf{O}$ & Al & $\mathrm{Ti}$ & $\mathrm{Cu}$ & $\mathrm{Cl} *$ \\
\hline $\mathrm{Cu} / \mathrm{Ti}$ & 5.84 & 65.93 & - & 26.84 & 0.99 & 0.41 \\
\hline $\mathrm{Cu} / \mathrm{Ti}-\mathrm{SCR}$ & 8.65 & 65.57 & - & 24.9 & 0.8 & - \\
\hline $\mathrm{Cu} / \mathrm{Ti}_{0.9} \mathrm{Al}_{0.1}$ & 4.59 & 64.89 & 6.44 & 23.08 & 0.59 & 0.4 \\
\hline $\mathrm{Cu} / \mathrm{Ti}_{0.9} \mathrm{Al}_{0.1}-\mathrm{SCR}$ & 5.09 & 65.47 & 5.83 & 22.86 & 0.75 & - \\
\hline $\mathrm{Cu} / \mathrm{Ti}_{0.8} \mathrm{Al}_{0.2}$ & 4.62 & 65.63 & 8.22 & 20.6 & 0.52 & 0.4 \\
\hline $\mathrm{Cu} / \mathrm{Ti}_{0.8} \mathrm{Al}_{0.2}-\mathrm{SCR}$ & 5.55 & 65.28 & 8.55 & 20.04 & 0.58 & - \\
\hline $\mathrm{Cu} / \mathrm{Ti}_{0.7} \mathrm{Al}_{0.3}$ & 5.69 & 63.52 & 12.49 & 17.22 & 0.46 & 0.61 \\
\hline $\mathrm{Cu} / \mathrm{Ti}_{0.7} \mathrm{Al}_{0.3}-\mathrm{SCR}$ & 5.9 & 64.08 & 12.3 & 17.19 & 0.54 & - \\
\hline $\mathrm{Cu} / \mathrm{Ti}_{0.6} \mathrm{Al}_{0.4}$ & 5.33 & 63.82 & 16.83 & 13.03 & 0.41 & 0.57 \\
\hline $\mathrm{Cu} / \mathrm{Ti}_{0.6} \mathrm{Al}_{0.4}-\mathrm{SCR}$ & 3.18 & 65.45 & 16.6 & 14.27 & 0.51 & - \\
\hline
\end{tabular}

* The presence of chloride is caused by its trace concentration in titanium isopropoxide used in the synthesis of aluminum doped titania precursors.

The $\mathrm{O} 1 \mathrm{~s}$ spectra (Figure 5a) of fresh catalysts show four components: (i) a main line (over $70 \%$ of total spectrum area) located at $529.7-530.1 \mathrm{eV}$ related to oxygen in titania [7], (ii) oxygen from defective $\mathrm{CuO}$ or $\mathrm{Cu}_{2} \mathrm{O}(\mathrm{BE}=530.4-531.2 \mathrm{eV})$ [8], (iii) peak at $\mathrm{BE}>531.9 \mathrm{eV}$ assigned to $\mathrm{OH}$ groups, and oxygen of organic contaminants, and (iv) very weak contribution at 528.0-528.4 eV, which can be referred to $\mathrm{Cu}$-Ti-O bonds (Table SA1 in Supporting Information). Relative increase in aluminum in catalysts causes increase in the component with $\mathrm{BE}=530.4-531.2 \mathrm{eV}$ at the cost of reducing the area of titania component. Thus, it strongly suggests that $\mathrm{Al}-\mathrm{O}$ bonds can contribute to this component. Similar $\mathrm{BE}$ range of $\mathrm{O} 1 \mathrm{~s}$ line ( 530.5 to $531.1 \mathrm{eV}$ ) was referred to the thin films of $\mathrm{Al}_{2} \mathrm{O}_{3}$ [9]. However, Severino et al. [10] have reported O $1 \mathrm{~s} \mathrm{component} \mathrm{with} \mathrm{BE}$ in the region of 529.7 to $531.9 \mathrm{eV}$ for $\mathrm{CuAl}_{2} \mathrm{O}_{4}$ spinel, and this possibility cannot be excluded. 

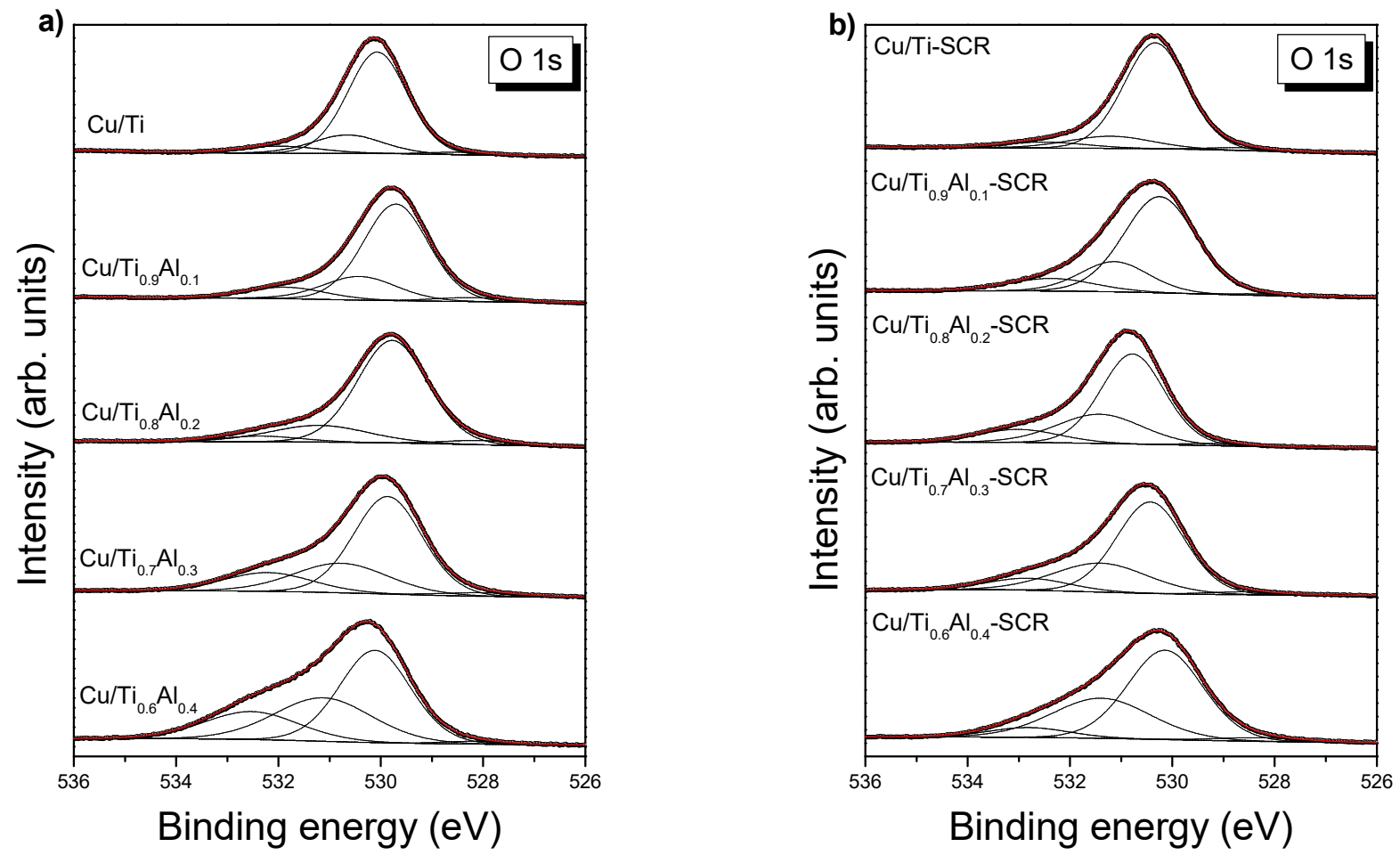

Figure 5. O 1s XPS spectra of fresh (a) and used (b) catalysts.

The $\mathrm{O}$ 1s spectra of spent catalysts (Figure $5 b$ ) can be described by similar four components as well. Binding energies of oxygen components coming from titania and defective copper oxides are slightly shifted towards higher energies (Tables SA1 and SA2 in Supporting Information). It can be caused by reoxidation of samples after SCR process due to their storage under air atmosphere.

The $\mathrm{C}$ 1s core lines (Figure S2, Supporting Information) for fresh and used catalysts are composed of three peaks at $285.0 \mathrm{eV}$ (organic contaminants), 286.0-286.6 eV (C-O groups), and $289.0-289.7 \mathrm{eV}(\mathrm{O}-\mathrm{C}=\mathrm{O}$ groups). The used catalysts show a bit higher content of $\mathrm{C}-\mathrm{O}$ groups $(20-35 \%)$ in comparison to fresh ones $(9-26 \%)$, whereas the amount of O-C=O groups remains unchanged after SCR process (Supporting Information, Tables SB1 and SB2). The hydrocarbon contamination was used as an internal calibration for our samples, as we mentioned above.

Single $\mathrm{Al} 2 \mathrm{p}$ component was detected with $\mathrm{Al} 2 \mathrm{p}_{3 / 2} \mathrm{BE}$ values close to $74.0 \mathrm{eV}$ and $74.3 \mathrm{eV}$ for fresh and used catalysts, respectively (Tables 3 and 4). Such contribution can be associated with the $\mathrm{Al}^{3+}$, similar to the case of $\mathrm{Al}_{2} \mathrm{O}_{3}[11,12]$. The spin-orbit splitting of $\mathrm{Al}$ $2 \mathrm{p}$ doublet was constrained to $\Delta_{\mathrm{SO}}=0.41 \mathrm{eV}$.

Table 3. XPS data of fresh catalysts.

\begin{tabular}{|c|c|c|c|c|c|c|c|c|c|c|}
\hline \multirow{3}{*}{ Core Excitation } & \multicolumn{2}{|c|}{$\mathrm{Cu} / \mathrm{Ti}$} & \multicolumn{2}{|c|}{$\mathrm{Cu} / \mathrm{Ti}_{0.9} \mathrm{Al}_{0.1}$} & \multicolumn{2}{|c|}{$\mathrm{Cu} / \mathrm{Ti}_{0.8} \mathrm{Al}_{0.2}$} & \multirow{2}{*}{\multicolumn{2}{|c|}{$\begin{array}{c}\mathrm{Cu} / \mathrm{Ti}_{0.7} \mathrm{Al}_{0.3} \\
\text { BE(eV) Area (\%) }\end{array}$}} & \multirow{2}{*}{\multicolumn{2}{|c|}{$\begin{array}{c}\mathrm{Cu} / \mathrm{Ti}_{0.6} \mathrm{Al}_{0.4} \\
\text { BE(eV) Area (\%) }\end{array}$}} \\
\hline & \multicolumn{2}{|c|}{ BE(eV) Area (\%) } & \multicolumn{2}{|c|}{ BE(eV) Area (\%) } & \multicolumn{2}{|c|}{ BE(eV) Area (\%) } & & & & \\
\hline & 930.3 & 2.0 & 930.7 & 2.0 & 930.3 & 4.5 & 930.1 & 4.1 & 930.8 & 5.4 \\
\hline \multirow[t]{2}{*}{$\mathrm{Cu} 2 \mathrm{p}_{3 / 2}$} & 932.7 & 91.2 & 932.6 & 90.5 & 932.5 & 93.3 & 932.6 & 92.9 & 932.8 & 91.1 \\
\hline & 934.1 & 6.8 & 935.0 & 7.5 & 935.0 & 2.2 & 935.6 & 3.0 & 935.8 & 2.5 \\
\hline Ti $2 p$ & 458.9 & 100 & 458.5 & 100 & 458.6 & 100 & 458.6 & 100 & 458.7 & 100 \\
\hline $\mathrm{Al} 2 \mathrm{p}_{3 / 2}$ & \multicolumn{2}{|c|}{ - } & 74.0 & 100 & 74.0 & 100 & 74.0 & 100 & 74.2 & 100 \\
\hline
\end{tabular}


Table 4. XPS data of used catalysts.

\begin{tabular}{|c|c|c|c|c|c|c|c|c|c|c|}
\hline \multirow{2}{*}{ Core Excitation } & \multicolumn{2}{|c|}{ Cu/Ti-SCR } & \multicolumn{2}{|c|}{$\mathrm{Cu} / \mathrm{Ti}_{0.9} \mathrm{Al}_{0.1}$-SCR } & \multicolumn{2}{|c|}{$\mathrm{Cu} / \mathrm{Ti}_{0.8} \mathrm{Al}_{0.2}$-SCR } & \multicolumn{2}{|c|}{$\mathrm{Cu} / \mathrm{Ti}_{0.7} \mathrm{Al}_{0.3}-\mathrm{SCR}$} & \multicolumn{2}{|c|}{$\mathrm{Cu} / \mathrm{Ti}_{0.6} \mathrm{Al}_{0.4}-\mathrm{SCR}$} \\
\hline & \multicolumn{2}{|c|}{ BE(eV) Area (\%) } & \multicolumn{2}{|c|}{ BE(eV) Area (\%) } & \multicolumn{2}{|c|}{ BE(eV) Area (\%) } & \multicolumn{2}{|c|}{ BE(eV) Area (\%) } & \multicolumn{2}{|c|}{ BE(eV) Area (\%) } \\
\hline \multirow{3}{*}{$\mathrm{Cu} 2 \mathrm{p}_{3 / 2}$} & 930.2 & 3.4 & 930.6 & 4.4 & 931.0 & 2.8 & 931.1 & 6.1 & 931.4 & 8.3 \\
\hline & 932.4 & 95.3 & 933.0 & 94.1 & 933.0 & 92.3 & 932.9 & 92.8 & 932.9 & 87.0 \\
\hline & 935.3 & 1.3 & 935.9 & 1.5 & 935.2 & 4.9 & 935.3 & 1.1 & 935.6 & 4.7 \\
\hline $\mathrm{Ti} 2 \mathrm{p}_{3 / 2}$ & 459.1 & 100 & 458.5 & 100 & 459.4 & 100 & 458.9 & 100 & 458.8 & 100 \\
\hline $\mathrm{Al} 2 \mathrm{p}_{3 / 2}$ & \multicolumn{2}{|c|}{-} & 74.2 & 100 & 74.4 & 100 & 74.2 & 100 & 74.3 & 100 \\
\hline
\end{tabular}

The Ti 2 p spectra can also be well fitted by a single symmetric doublet with the spinorbit splitting of $5.74 \mathrm{eV}$. Ti $2 \mathrm{p}_{3 / 2} \mathrm{BE}$ values of $458.5-459.1 \mathrm{eV}$ are characteristic for the presence of $\mathrm{Ti}(\mathrm{IV})[7,13-16]$. One can identify that the highest Ti $2 \mathrm{p}_{3 / 2} \mathrm{BE}$ of $459.4 \mathrm{eV}$ was found in $\mathrm{Cu} / \mathrm{Ti}_{0.8} \mathrm{Al}_{0.2}$-SCR.

Figure 6 presents XPS spectra of fresh and used catalysts at $\mathrm{Cu} 2 \mathrm{p}$ region. In addition to well separated spin-orbit peaks with total momentum $\mathrm{j}=3 / 2$ and $\mathrm{j}=\frac{1}{2}$, there are much weaker additional structures between them related to shake-up satellites. The satellite peaks are characteristic of $\mathrm{Cu}(\mathrm{II})$ which has a $\mathrm{d}^{9}$ configuration in the ground state and may occur when the outgoing photoelectrons interacts with valence electrons exciting to higher-energy levels. The shake-up satellites are absent in $\mathrm{d}^{10} \mathrm{Cu}^{0}$ or $\mathrm{Cu}^{+}$spectra. It is generally accepted that much stronger shake-up structures are associated with more $\mathrm{Cu}^{2+}$ species in the sample $[17,18]$.
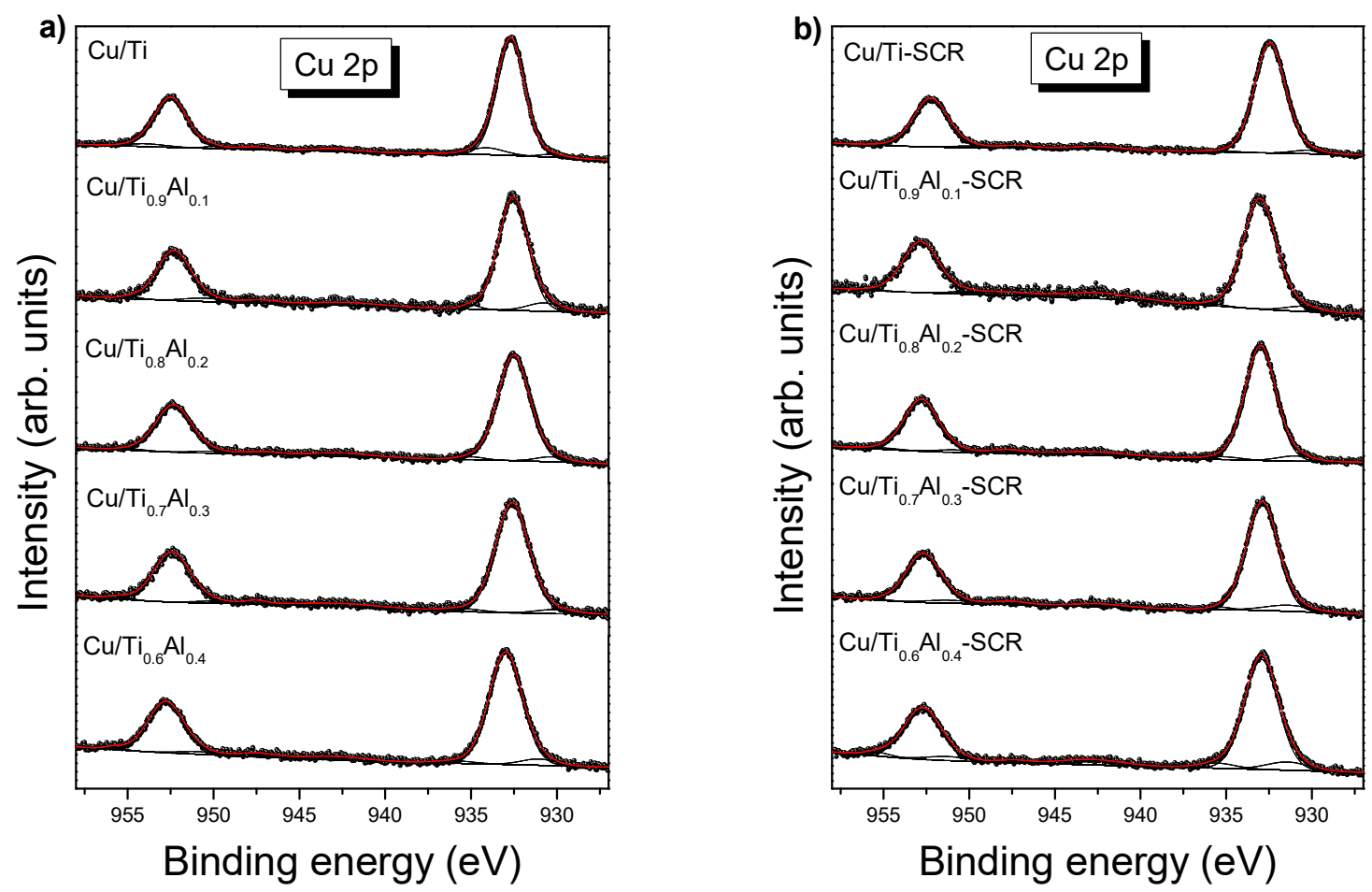

Figure 6. Cu 2p XPS spectra of fresh (a) and used (b) catalysts.

The Cu 2p XPS spectra (Figure 6) of all catalysts are described by three components, which can be assigned to lower valence $\mathrm{Cu}\left(\mathrm{Cu}^{0}\right.$ at $\mathrm{BE}$ of $\mathrm{Cu} 2 \mathrm{p}_{3 / 2}<931.4 \mathrm{eV}$ and $\mathrm{Cu}^{+}$at 932.5-933.0 eV) and to $\mathrm{Cu}^{2+}$ species ( 935.0 eV). The most dominating component (>90\% of total spectrum area) attributed to $\mathrm{Cu}$ ions in $\mathrm{Cu}-\mathrm{O}$-Ti sites with a binding energy typical of $\mathrm{Cu}^{+}$demonstrates that redox reduction occurs between $\mathrm{Cu}^{2+}$ precursor and $\mathrm{Ti}^{3+}$ in surface defective sites of $\mathrm{TiO}_{2}$ to produce the $\mathrm{Cu}^{+}$species strongly interacting with $\mathrm{TiO}_{2}$, as reported previously [19]. We tentatively assigned the $\mathrm{Cu}^{2+} \mathrm{XPS}$ signal to $\mathrm{CuAl}_{2} \mathrm{O}_{4}$ or $\mathrm{Cu}(\mathrm{OH})_{2}$ for which very near BE were reported [8,11,17]. On the other hand, Shen et al. [18] 
reported peak at $934.9 \mathrm{eV}$ as the ionic $\mathrm{Cu}^{2+}$ binding in $\mathrm{CuO}$ phase, whereas the covalent part of $\mathrm{Cu}^{2+}$ was attributed to $933.4 \mathrm{eV}$ peak position. The distinction between copper oxidation states needs some comment. The absolute BE values of $\mathrm{Cu} 2 \mathrm{p}$ peaks are rarely helpful in identifying the copper oxidation state, since only small differences between $\mathrm{Cu}^{+}$ and $\mathrm{Cu}^{0}$, and between octahedral $\mathrm{Cu}^{2+}$ and $\mathrm{Cu}^{+}$are reported in the literature $[8,20,21]$. In such a case, distinguishing between $\mathrm{Cu}^{+}$and $\mathrm{Cu}^{0}$ species can be drawn from the $\mathrm{Cu}$ $2 \mathrm{p}_{3 / 2}-\mathrm{Cu} \mathrm{L} \mathrm{M}_{45} \mathrm{M}_{45}$ Wagner plot $[8,22]$. The kinetic energy of maximum of $\mathrm{Cu} \mathrm{L}_{3} \mathrm{M}_{45} \mathrm{M}_{45}$ Auger peak was obtained from the survey spectra, whereas BE of the major component from the $\mathrm{Cu} 2 \mathrm{p}$ high-resolution spectra (Table 5). The copper Auger parameter for such a contribution is close to $1849 \mathrm{eV}$ for all measured samples. It is worth noting that Auger parameters of $1851.2 \mathrm{eV}$ (metallic $\mathrm{Cu}), 1849.2 \mathrm{eV}\left(\mathrm{Cu}_{2} \mathrm{O}\right), 1851.3 \mathrm{eV}(\mathrm{CuO})$ and $1850.9 \mathrm{eV}$ $\left(\mathrm{Cu}(\mathrm{OH})_{2}\right)$ were reported by Biesinger et al. [8,17]. Taking into account above values and drawing the copper Wagner plot, we can attribute the most intense component to $\mathrm{Cu}^{+}$ species [22]. This result, together with very weak shake-up satellites can point out that the dominating oxidation state of copper in all catalysts is +1 .

Table 5. Spectral fitting parameters for $\mathrm{Cu} 2 \mathrm{p}_{3 / 2}$ lines of fresh catalysts: binding energy $(\mathrm{eV})$ and percentage of total area (in parentheses). The kinetic energy of CuLMM and Auger parameter are also listed.

\begin{tabular}{|c|c|c|c|c|c|}
\hline Sample & $\mathrm{Cu}^{0}$ & $\mathrm{Cu}^{+}$ & $\mathrm{Cu}^{2+}$ & KE of $\mathrm{Cu} \mathrm{L} \mathrm{L}_{3} \mathrm{M}_{45} \mathrm{M}_{45}$ & Auger Parameter \\
\hline $\mathrm{Cu} / \mathrm{Ti}$ & $\begin{array}{c}930.3 \\
(2)\end{array}$ & $\begin{array}{l}932.7 \\
(91.2)\end{array}$ & $\begin{array}{c}934.1 \\
(6.8)\end{array}$ & 916.3 & 1849 \\
\hline $\mathrm{Cu} / \mathrm{Ti}_{0.9} \mathrm{Al}_{0.1}$ & $\begin{array}{c}930.8 \\
(7.5)\end{array}$ & $\begin{array}{l}932.6 \\
(90.5)\end{array}$ & $\begin{array}{l}935 \\
(2)\end{array}$ & 916.5 & 1849.1 \\
\hline $\mathrm{Cu} / \mathrm{Ti}_{0.8} \mathrm{Al}_{0.2}$ & $\begin{array}{c}930.3 \\
(4.5)\end{array}$ & $\begin{array}{l}932.5 \\
(93.3)\end{array}$ & $\begin{array}{c}935 \\
(2.2)\end{array}$ & 916.6 & 1849.1 \\
\hline $\mathrm{Cu} / \mathrm{Ti}_{0.7} \mathrm{Al}_{0.3}$ & $\begin{array}{c}930.1 \\
(4.1)\end{array}$ & $\begin{array}{l}932.6 \\
(92.9)\end{array}$ & $\begin{array}{c}935.6 \\
\text { (3) }\end{array}$ & 916.3 & 1848.9 \\
\hline $\mathrm{Cu} / \mathrm{Ti}_{0.6} \mathrm{Al}_{0.4}$ & $\begin{array}{c}931.1 \\
(5.4)\end{array}$ & $\begin{array}{c}933 \\
(92.1)\end{array}$ & $\begin{array}{c}936 \\
(2.5)\end{array}$ & no data * & no data \\
\hline
\end{tabular}

${ }^{*}$ The $\mathrm{Cu} \mathrm{L}{ }_{3} \mathrm{M}_{45} \mathrm{M}_{45}$ spectra of $\mathrm{Cu} / \mathrm{Ti}_{0.6} \mathrm{Al}_{0.4}$ and $\mathrm{Cu} / \mathrm{Ti}_{0.6} \mathrm{Al}_{0.4}$-SCR were also measured but failed to provide useful information due to the interference with Ti $2 \mathrm{~s}$ XPS and strong surface plasmon signals.

The SCR process resulted only in a small increase in $\mathrm{Cu}^{0}$ contribution, especially well visible in high-Al catalysts (Tables 5 and 6). One can see also a small BE shift of $\mathrm{Cu}^{2+}$ component towards higher energies. As we mentioned above, it can be caused by reoxidation of samples after SCR process due to their storage under air atmosphere.

Table 6. Spectral fitting parameters for $\mathrm{Cu} 2 \mathrm{p}_{3 / 2}$ lines of used catalysts: binding energy $(\mathrm{eV})$ and percentage of total area (in parentheses). The kinetic energy of $\mathrm{CuLMM}(\mathrm{eV})$ and Auger parameter $(\mathrm{eV})$ are also listed.

\begin{tabular}{|c|c|c|c|c|c|}
\hline Sample & $\mathrm{Cu}^{0}$ & $\mathrm{Cu}^{+}$ & $\mathrm{Cu}^{2+}$ & KE of CuLMM & Auger Parameter \\
\hline $\mathrm{Cu} / \mathrm{Ti}-\mathrm{SCR}$ & $\begin{array}{c}930.2 \\
(3.4)\end{array}$ & $\begin{array}{l}932.4 \\
(95.3)\end{array}$ & $\begin{array}{c}935.3 \\
(1.3)\end{array}$ & 915.9 & 1848.7 \\
\hline $\mathrm{Cu} / \mathrm{Ti}_{0.9} \mathrm{Al}_{0.1}-\mathrm{SCR}$ & $\begin{array}{c}930.6 \\
(4.4)\end{array}$ & $\begin{array}{c}933 \\
(94.1)\end{array}$ & $\begin{array}{c}935.9 \\
(1.5)\end{array}$ & 916.4 & 1849.4 \\
\hline $\mathrm{Cu} / \mathrm{Ti}_{0.8} \mathrm{Al}_{0.2}-\mathrm{SCR}$ & $\begin{array}{c}931 \\
(4.9)\end{array}$ & $\begin{array}{c}933 \\
(93.3)\end{array}$ & $\begin{array}{c}935.2 \\
(2.8)\end{array}$ & 916.3 & 1849.3 \\
\hline $\mathrm{Cu} / \mathrm{Ti}_{0.7} \mathrm{Al}_{0.3}-\mathrm{SCR}$ & $\begin{array}{c}931.4 \\
(7.8)\end{array}$ & $\begin{array}{l}932.9 \\
(90.8)\end{array}$ & $\begin{array}{c}935.3 \\
(1.4)\end{array}$ & 916.1 & 1849 \\
\hline $\mathrm{Cu} / \mathrm{Ti}_{0.6} \mathrm{Al}_{0.4}-\mathrm{SCR}$ & $\begin{array}{l}931.4 \\
(8.3)\end{array}$ & $\begin{array}{c}932.9 \\
(87)\end{array}$ & $\begin{array}{c}935.6 \\
(4.7)\end{array}$ & no data * & no data \\
\hline
\end{tabular}

* The $\mathrm{Cu} \mathrm{L}{ }_{3} \mathrm{M}_{45} \mathrm{M}_{45}$ spectra of $\mathrm{Cu} / \mathrm{Ti}_{0.6} \mathrm{Al}_{0.4}$ and $\mathrm{Cu} / \mathrm{Ti}_{0.6} \mathrm{Al}_{0.4}$-SCR were also measured but failed to provide useful information due to the interference with Ti $2 \mathrm{~s}$ XPS and strong surface plasmon signals.

The absence of $\mathrm{Cu}^{0} / \mathrm{Cu}^{+} \mathrm{XRD}$ signals together with XPS results suggest the high dispersion of copper species on the catalyst surfaces. The synergistic interaction between 
$\mathrm{Ti}$ and $\mathrm{Cu}$, which promotes the reducibility of $\mathrm{CuO}$, giving rise to the formation of surface $\mathrm{Cu}^{+}$, as shown by XPS analysis, appears to play a significant role in determining the catalyst efficiency.

\subsection{Catalytic Activity}

$\mathrm{NO}$ conversion and $\mathrm{N}_{2} \mathrm{O}$ formation in SCR of $\mathrm{NO}$ with ammonia over $\mathrm{Cu} / \mathrm{Ti}_{\mathrm{x}} \mathrm{Al}_{1-\mathrm{x}}$ catalysts are presented in Figure 7. For the $\mathrm{Cu} / \mathrm{Ti}$ catalyst, with pure $\mathrm{TiO}_{2}$ as a support, above $80 \%$ of conversion was observed in the temperature range of $250{ }^{\circ} \mathrm{C}$ to $350{ }^{\circ} \mathrm{C}$, with the maximum of ca. $90 \%$ at $300{ }^{\circ} \mathrm{C}$. The substitution of $10 \%$ of titanium with aluminum resulted in a few percent increase in the catalytic activity between $250{ }^{\circ} \mathrm{C}$ and $400{ }^{\circ} \mathrm{C}$. A further increase in $\mathrm{Al}$ content caused broadening of the temperature window of $80 \%$ NO conversion up to $400{ }^{\circ} \mathrm{C}$ as registered for the $\mathrm{Cu} / \mathrm{Ti}_{0.8} \mathrm{Al}_{0.2}$ and $\mathrm{Cu} / \mathrm{Ti}_{0.7} \mathrm{Al}_{0.3}$ samples. This better catalytic activity could result from higher copper dispersion on the catalysts surface and from its presence in $\mathrm{Cu}-\mathrm{O}-\mathrm{Ti}$ bonds in the form of $\mathrm{Cu}^{+}$cations (Tables 5 and 6). For the sample with maximum aluminum concentration $\mathrm{Cu} / \mathrm{Ti}_{0.6} \mathrm{Al}_{0.4}$ the maximum activity is significantly shifted to higher temperatures, $\mathrm{NO}$ conversion $>80 \%$ was attained in the temperature range of $300^{\circ} \mathrm{C}$ to $400{ }^{\circ} \mathrm{C}$ and maximum at $400{ }^{\circ} \mathrm{C}$. This shift could be caused by higher $\mathrm{Al}$ content causing the increase in Brønsted acidity. During catalytic tests the small amounts of $\mathrm{N}_{2} \mathrm{O}$ formation was observed. The $\mathrm{N}_{2} \mathrm{O}$ concentration was below the threshold limit of $30 \mathrm{ppm}$ for all aluminum-doped catalysts. The lowest values were measured for the sample with the highest $\mathrm{Al}$ content. For the titania supported catalyst the $\mathrm{N}_{2} \mathrm{O}$ concentration achieved ca. $40 \mathrm{ppm}$ at temperatures related to its highest catalytic activity $\left(250-350^{\circ} \mathrm{C}\right)$.

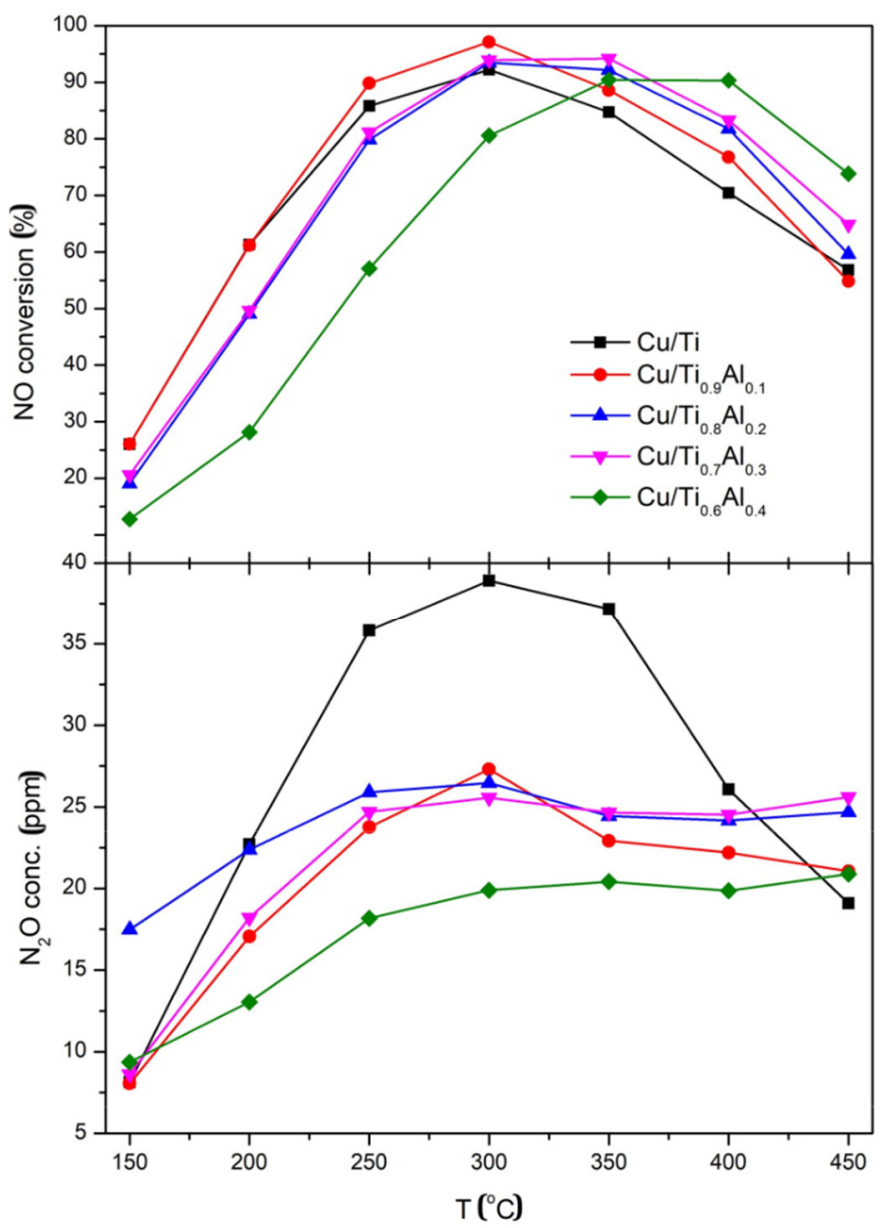

Figure 7. $\mathrm{NO}$ conversion and $\mathrm{N}_{2} \mathrm{O}$ concentration over $\mathrm{Cu} / \mathrm{Ti}_{x} \mathrm{Al}_{1-\mathrm{x}}$ catalysts. 


\section{Conclusions}

Aluminum doped titania precursors were obtained by the sol-gel method. They attained mass stability at $450{ }^{\circ} \mathrm{C}$ and after calcination and copper deposition, they were tested as catalysts in SCR of NO. XRD results showed that titania crystallized as anatase phase whereas aluminum and copper oxides remained amorphous. Specific surface area of mesoporous samples increased with aluminum concentration to above $100 \mathrm{~m}^{2} \mathrm{~g}^{-1}$, whereas their average pore size shifted to lower values. Catalytic tests showed that $\mathrm{Al}$ admixture to the titania support caused that the temperature range of high activity was broadened and shifted to higher temperatures in the case of sample with maximum aluminum content. The samples containing aluminum caused the formation of only trace amount of $\mathrm{N}_{2} \mathrm{O}$. The improvement of catalytic efficiency was caused by good copper dispersion on the catalyst surface resulting from the specific surface development of aluminum doped titania supports. The copper surface species contained mainly $\mathrm{Cu}^{+}$cations and occurred in $\mathrm{Cu}-\mathrm{O}-$ Ti bonds. Thus, one can say that the catalyst efficiency improvement was achieved by the synergistic interaction between $\mathrm{Ti}$ and $\mathrm{Cu}$, and hence the reducibility of $\mathrm{CuO}$.

Supplementary Materials: The following are available online at https: / www.mdpi.com/article / 10.3390/ma14206021/s1, Table SA1: XPS O 1s data of fresh catalysts, Table SA2: XPS O 1s data of used catalysts Table SB1. XPS C 1s data of fresh catalysts., Table SB2. XPS C 1s data of used catalysts. Figure S1. TG, DTG and DSC curves for titania (A) and $\mathrm{Ti}_{0.9} \mathrm{Al}_{0.1}$ (B) precursors., Figure S2. C 1s XPS spectra of fresh (a) and used (b) catalysts.

Author Contributions: Conceptualization, A.B.; investigation, W.G., A.B., B.D.N., M.Z. and J.G.; data curation, W.G., A.B., B.D.N., M.Z. and J.G.; writing-original draft preparation, A.B. and J.G.; visualization W.G., M.Z. and J.G.; supervision, A.B. All authors have read and agreed to the published version of the manuscript.

Funding: This research was financed from Research Subvention AGH UST No 16.16.210.476.

Institutional Review Board Statement: Not applicable.

Informed Consent Statement: Not applicable.

Data Availability Statement: The data presented in this study are available on request from the corresponding author.

Acknowledgments: We thank Grzegorz Mordarski (Institute of Catalysis and Surface Chemistry PAS) for providing the XRF characterization of all samples.

Conflicts of Interest: The authors declare no conflict of interest.

\section{References}

1. Han, L.; Cai, S.; Gao, M.; Hasegawa, J.Y.; Wang, P.; Zhang, J.; Shi, L.; Zhang, D. Selective Catalytic Reduction of NOx with $\mathrm{NH}_{3}$ by Using Novel Catalysts: State of the Art and Future Prospects. Chem. Rev. 2019, 119, 10916-10976. [CrossRef]

2. Wang, X.; Shi, Y.; Li, S.; Li, W. Promotional synergistic effect of $\mathrm{Cu}$ and $\mathrm{Nb}$ doping on a novel $\mathrm{Cu} / \mathrm{Ti}-\mathrm{Nb}$ ternary oxide catalyst for the selective catalytic reduction of NOx with NH3. Appl. Catal. B Environ. 2018, 220, 250. [CrossRef]

3. Blanco, J.; Avila, P.; Suárez, S.; Martín, J.A.; Knapp, C. Alumina- and titania-based monolithic catalysts for low temperature selective catalytic reduction of nitrogen oxides. Appl. Catal. B Environ. 2000, 28, 235-244. [CrossRef]

4. Suárez, S.; Martín, J.A.; Yates, M.; Avila, P.; Blanco, J. $\mathrm{N}_{2} \mathrm{O}$ formation in the selective catalytic reduction of $\mathrm{NOx}_{\text {with }} \mathrm{NH}_{3}$ at low temperature on CuO-supported monolithic catalysts. J. Catal. 2005, 229, 227-236. [CrossRef]

5. Bennici, S.; Carniti, P.; Gervasini, A. Bulk and surface properties of dispersed CuO phases in relation with activity of NOx reduction. Catal. Lett. 2004, 98, 187-194. [CrossRef]

6. Tanuma, S.; Powell, C.J.; Penn, D.R. Calculations of electron inelastic mean free paths. V. Data for 14 organic compounds over the 50-2000 eV range. Surf. Interface Anal. 1994, 21, 165-176. [CrossRef]

7. Yu, Z.; Zhang, Z.; Zhang, Y.; Huang, W. Titania Morphology-Dependent Catalysis of CuOx/TiO2 Catalysts in CO Oxidation and Water Gas Shift Reactions. ChemCatChem 2020, 12, 3679-3686. [CrossRef]

8. Biesinger, M.C. Advanced analysis of copper X-ray photoelectron spectra. Surf. Interface Anal. 2017, 49, 1325-1334. [CrossRef]

9. Dhonge, B.P.; Mathews, T.; Sundari, S.T.; Thinaharan, C.; Kamruddin, M.; Dash, S.; Tyagi, A.K. Spray pyrolytic deposition of transparent aluminum oxide (Al 2 O 3 ) films. Appl. Surf. Sci. 2011, 258, 1091-1096. [CrossRef] 
10. Severino, F.; Brito, J.L.; Laine, J.; Fierro, J.L.G.; López Agudo, A. Nature of copper active sites in the carbon monoxide oxidation on $\mathrm{CuAl} 2 \mathrm{O} 4$ and $\mathrm{CuCr} 2 \mathrm{O} 4$ spinel type catalysts. J. Catal. 1998, 177, 82-95. [CrossRef]

11. Ponmudi, S.; Sivakumar, R.; Sanjeeviraja, C.; Gopalakrishnan, C.; Jeyadheepan, K. Facile fabrication of spinel structured n-type $\mathrm{CuAl}_{2} \mathrm{O}_{4}$ thin film with nano-grass like morphology by sputtering technique. Appl. Surf. Sci. 2019, 483, 601-615. [CrossRef]

12. $\mathrm{Hu}, \mathrm{B} . ;$ Yao, M.; Xiao, R.; Chen, J.; Yao, X. Optical properties of amorphous $\mathrm{Al}_{2} \mathrm{O}_{3}$ thin films prepared by a sol-gel process. Ceram. Int. 2014, 40, 14133-14139. [CrossRef]

13. Bertóti, I.; Mohai, M.; Sullivan, J.L.; Saied, S.O. Surface characterisation of plasma-nitrided titanium: An XPS study. Appl. Surf. Sci. 1995, 84, 357-371. [CrossRef]

14. Greczynski, G.; Hultman, L. Self-consistent modelling of X-ray photoelectron spectra from air-exposed polycrystalline TiN thin films. Appl. Surf. Sci. 2016, 387, 294-300. [CrossRef]

15. Bukhtiyarov, V.I. XPS and SIMS characterization. Catal. Today 2000, 56, 403-413. [CrossRef]

16. Jaeger, D.; Patscheider, J. A complete and self-consistent evaluation of XPS spectra of TiN. J. Electron Spectros. Relat. Phenom. 2012, 185, 523-534. [CrossRef]

17. Biesinger, M.C.; Lau, L.W.; Gerson, A.R.; StC Smart, R. Resolving surface chemical states in XPS analysis of first row transition metals, oxides and hydroxides: Sc, Ti, V, Cu and Zn. Appl. Surf. Sci. 2010, 257, 887-898. [CrossRef]

18. Shen, Y.; Guo, M.; Xia, X.; Shao, G. Role of materials chemistry on the electrical/electronic properties of CuO thin films. Acta Mater. 2015, 85, 122-131. [CrossRef]

19. Liu, Y.; Zhang, B.; Luo, L.; Chen, X.; Wang, Z.; Wu, E.; Su, D.; Huang, W. TiO2/Cu2O Core/Ultrathin Shell Nanorods as Efficient and Stable Photocatalysts for Water Reduction. Angew. Chem. Int. Ed. 2015, 54, 15260-15265. [CrossRef] [PubMed]

20. Białas, A.; Rugała, K.; Czosnek, C.; Mordarski, G.; Gurgul, J. Copper aluminum spinels doped with cerium as catalysts for NO removal. Catalysts 2020, 10, 1388. [CrossRef]

21. Ghijsen, J.; Tjeng, L.H.; Van Elp, J.; Eskes, H.; Westerink, J.; Sawatzky, G.A.; Czyzyk, M.T. Electronic structure of Cu $\mathrm{O}_{2}$ and CuO. Phys. Rev. B 1988, 38, 11322-11338. [CrossRef] [PubMed]

22. NIST XPS Database. Available online: https://srdata.nist.gov/xps (accessed on 10 September 2021). 